\title{
Correction \\ Correction: Farkas et al. Concentration and Quantification of SARS-CoV-2 RNA in Wastewater Using Polyethylene Glycol-Based Concentration and qRT-PCR. Methods Protoc. $2021,4,17$
}

Kata Farkas ${ }^{1,2, *}$, , Luke S. Hillary ${ }^{1}{ }^{(\mathbb{D}}$, Jamie Thorpe ${ }^{1,2}{ }^{2}$ David I. Walker ${ }^{3}$, James A. Lowther ${ }^{3}$, James E. McDonald ${ }^{1}$, Shelagh K. Malham ${ }^{2}$ and Davey L. Jones ${ }^{1,4}$

1 School of Natural Sciences, Bangor University, Deiniol Road, Bangor LL57 2UW, UK; luke.hillary@bangor.ac.uk (L.S.H.); osp82d@bangor.ac.uk (J.T.); j.mcdonald@bangor.ac.uk (J.E.M.); d.jones@bangor.ac.uk (D.L.J.)

2 School of Ocean Sciences, Bangor University, Menai Bridge LL59 5AB, UK; s.malham@bangor.ac.uk

3 UK National Reference Laboratory for Foodborne Viruses, Centre for Environment, Fisheries and Aquaculture Science, Weymouth DT4 8UB, UK; david.walker@cefas.co.uk (D.I.W.); james.lowther@cefas.co.uk (J.A.L.)

4 UWA School of Agriculture and Environment, The University of Western Australia, Perth, WA 6009, Australia

* Correspondence: fkata211@gmail.com

check for updates

Citation: Farkas, K.; Hillary, L.S.; Thorpe, J.; Walker, D.I.; Lowther, J.A.; McDonald, J.E.; Malham, S.K.; Jones, D.L. Correction: Farkas et al. Concentration and Quantification of SARS-CoV-2 RNA in Wastewater Using Polyethylene Glycol-Based Concentration and qRT-PCR. Methods Protoc. 2021, 4, 17. Methods Protoc. 2021, 4, 82. https://doi.org/ $10.3390 / \mathrm{mps} 4040082$

Received: 4 November 2021 Accepted: 9 November 2021 Published: 12 November 2021

Publisher's Note: MDPI stays neutral with regard to jurisdictional claims in published maps and institutional affiliations.

Copyright: (c) 2021 by the authors. Licensee MDPI, Basel, Switzerland. This article is an open access article distributed under the terms and conditions of the Creative Commons Attribution (CC BY) license (https:// creativecommons.org/licenses/by/ $4.0 /)$.
There was an error in the original article [1]. In Section 5, the volume of water to mix $100 \mathrm{~g}$ PEG 8000 was wrongly written as $800 \mathrm{~mL}$. A correction has been made to Section 5: Mix $100 \mathrm{~g}$ PEG 8000 with $400 \mathrm{~mL}$ water and mix on a magnetic stirrer until dissolved. The authors apologize for any inconvenience caused and state that the scientific conclusions are unaffected. The original article has been updated.

\section{Reference}

1. Farkas, K.; Hillary, L.S.; Thorpe, J.; Walker, D.I.; Lowther, J.A.; McDonald, J.E.; Malham, S.K.; Jones, D.L. Concentration and Quantification of SARS-CoV-2 RNA in Wastewater Using Polyethylene Glycol-Based Concentration and qRT-PCR. Methods Protoc. 2021, 4, 17. [CrossRef] 